This is an author produced version of a paper published in Journal of

Dairy Research. This paper has been peer-reviewed and is proofcorrected, but does not include the journal pagination.

Citation for the published paper:

Åkerstedt, M., Persson Waller, K., Sternesjö, Å. (2009) Haptoglobin and serum amyloid A in bulk tank milk in relationto raw milk quality.

Journal of Dairy Research.

Volume: 76 Number: 4, pp 483-489.

http://dx.doi.org/10.1017/S0022029909990185

Access to the published version may require journal subscription.

Published with permission from: Cambridge University Press

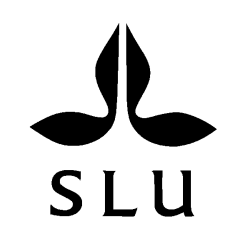

Epsilon Open Archive http://epsilon.slu.se 


\section{Haptoglobin and serum amyloid $A$ in bulk tank milk in relation to raw milk}

2

3

4

5

$6 \quad{ }^{1}$ Department of Food Science, Swedish University of Agricultural Sciences, SE-750

$7 \quad 07$ Uppsala, Sweden

$8 \quad{ }^{2}$ Department of Animal Health and Antimicrobial Strategies, National Veterinary

9 Institute, SE-751 89 Uppsala, Sweden

$10{ }^{3}$ Department of Clinical Sciences, Swedish University of Agricultural Sciences, SE-

1175007 Uppsala, Sweden

12

13

14 Short title: Hp, SAA and bulk tank milk quality

15

16

17

18

19

20

$21{ }^{*}$ Correspondence to: Maria Åkerstedt, Department of Food Science, Swedish

22 University of Agricultural Sciences, SE-750 07 Uppsala, Sweden.

23

Phone: +46-18-672040; Fax: +46-18-672995; e-mail: Maria.Akerstedt@lmv.slu.se 

6 7

\section{Summary}

The aim of the present study was to evaluate relationships between the presence of the two major bovine acute phase proteins haptoglobin (Hp) and serum amyloid A (SAA) and raw milk quality parameters in bulk tank milk samples. Hp and SAA have been suggested as specific markers of mastitis but recently also as markers for raw milk quality. Since mastitis has detrimental effects on milk quality, it is important to investigate if the presence of Hp or SAA indicates such changes in the composition and properties of the milk. Bulk tank milk samples ( $\mathrm{n}=91)$ were analysed for $\mathrm{Hp}$, SAA, total protein, casein, whey protein, proteolysis, fat, lactose, somatic cell count and coagulating properties. Samples with detectable levels of Hp had lower casein content, casein number and lactose content, but higher proteolysis than samples without Hp. Samples with detectable levels of SAA had lower casein number and lactose content, but higher whey protein content than samples without SAA. The presence of APP in bulk tank milk is suggested as an indicator for unfavourable changes in the milk composition, e.g. protein quality, due to udder health disturbances, with economical implications for the dairy industry.

\section{(1)} 4 3 4 5 8 49 
50 The bulk tank milk composition has a decisive influence on the production of safe,

51 high quality dairy products. One major factor responsible for the deterioration of the

52 quality of the raw milk is mastitis, and its negative effect on the milk composition is

53 well established (Kitchen, 1981; Munro et al. 1984). It is the sub-clinical form of

54 mastitis that constitutes problems to the dairies, since these cases often go undetected

55 and the milk is delivered to the dairy (Leitner et al. 2008). Studies show that during

56 mastitis the casein content, valuable for the cheese making industry, will decrease

57 while the whey protein content will increase (Barbano et al. 1991; Auldist et al. 1996;

58 Urech et al. 1999). In addition, increased proteolysis is often observed in milk from

59 cows with mastitis (Schaar, 1985; Auldist et al. 1996). Proteolysis in milk is one of

60 the major product deteriorating factors with negative impact on the quality and

61 stability of milk and dairy products (Mara et al. 1998; Kelly et al. 2006). Saeman et

62 al. (1988) found that after an udder infection the proteolytic activity may sustain even

63 though the SCC has returned to normal levels. Larsen et al. (2004) established that

64 casein degradation not only occurred in the infected quarter but also in the

65 neighbouring quarters, even though there was no effect on the SCC. In the bulk tank,

66 milk from healthy udder quarters will be commingled with milk from infected

67 quarters, and thus, the entire bulk tank may be affected by protein degradation. This is

68 a problem, especially for the cheese making industry, since curd formation properties

69 will be impaired and yield reduced (Mara et al. 1998, Leitner et al. 2008). Likewise,

70 proteolytic activity in UHT-milk may cause off flavours and gelation, and

71 consequently reduced shelf-life of the products (Ma et al. 2000; Santos et al. 2003;

72 Barbano et al. 2006; De Noni et al. 2007). 
Milk somatic cell count (SCC) has been used extensively since the 1960s in the diagnosis of mastitis, and the BTMSCC (bulk tank milk somatic cell count) is widely used in the assessment of raw milk quality. In many EU countries milk payment systems favours a low BTMSCC. There is, however, no clear scientific data defining the level of BTMSCC that is associated with additional benefits in terms of milk quality. Several authors have reported that SCC is not a suitable indicator of proteolysis in quarter milk samples (Le Roux et al. 1995; Urech et al. 1999) and recent studies have also shown that the BTMSCC gives a poor prediction of raw milk quality for cheese production (Leitner et al. 2008). Research to find new sensitive and specific markers for disadvantageous changes in raw milk composition due to udder health disturbances is therefore warranted.

The acute phase proteins (APP) have become important diagnostic markers of disease in human medicine and are also being evaluated in veterinary diagnostics (Eckersall, 2004). The major bovine APP are haptoglobin (Hp) and serum amyloid A (SAA), which both increase dramatically upon infection, inflammation or trauma. Hp and SAA are mainly produced by the liver but are also produced locally in the mammary gland (McDonald et al. 2001; Hiss et al. 2004). Some studies have found that Hp and SAA have antibacterial effects (Eaton et al. 1982; Hari-Dass et al. 2005; Larson et al. 2005) and considering that they are locally produced, their role in the inflammatory defence is interesting. In several studies Hp and SAA in milk have been evaluated as markers for mastitis (Horadagoda et al. 1999; Eckersall et al. 2001; Grönlund et al. 2003; Nielsen et al. 2004; Grönlund et al. 2005; Eckersall et al. 2006; Hiss et al. 2007), but so far little attention has been paid regarding their potential in predicting changes in milk composition and technological properties of the raw milk. In a 
previous study we reported that detectable levels of Hp and SAA could be found in bulk tank milk samples (Åkerstedt et al. 2007). In a more recent study we also investigated APP in relation to raw milk quality parameters in cow composite milk samples (Åkerstedt et al. 2008). To our knowledge, these papers are the only studies examining APP in bovine bulk tank milk or applying APP research in the field of product quality. However, no studies have been reported on Hp and SAA in relation to the quality of the raw bulk tank milk. Quality programs for milk payment and advisory measures to improve the raw milk quality are mostly based on analysis of bulk tank milk samples. For APP to be a potential candidate as indicator for unfavorable changes in milk composition due to udder health disturbances in the herd, it is important that levels of APP in the bulk tank milk are related to important quality traits of the raw milk.

The aim of this study was to investigate relationships between the presence of Hp and SAA, and different raw milk quality parameters, i.e. total protein, casein, whey protein, proteolysis, fat, lactose and SCC in bulk tank milk samples. In addition, APP in relation to the coagulating properties of the bulk tank milk samples were evaluated.

\section{Materials and methods}

\section{Bulk tank milk samples}

The study included 91 bulk tank milk samples collected from different dairy farms in cooperation with the Milko dairy cooperative (Grådö, Hedemora, Sweden). One representative sample from each farm was taken by the tanker driver just before emptying the bulk tank, in connection with the ordinary milk collection, which occurred every second day. At the sampling occasion the farms delivered 90-13,025 
$124 \mathrm{~kg}$ milk (average 1,610 kg), indicating that the herd size of the participating farms

125 varied markedly. The average BTMSCC for the samples was 195,000 cells/ml,

126 ranging from 33,000 to 1,365,000 cells/ml (median 146,000 cells/ml). The bulk tank

127 milk samples were collected at the dairy plant for further transportation to the

128 university laboratory the same day. Sample aliquots for the analyses of Hp, SAA and

129 proteolysis were frozen and stored at $-70^{\circ} \mathrm{C}$ until analysis, whereas the other

130 parameters were analysed using fresh milk samples.

Assay of haptoglobin and serum amyloid A

133 Hp was analysed by an earlier described optical biosensor assay (Åkerstedt et al.

134 2006; Åkerstedt et al. 2008) with some additional modifications. In this study, the Hp

135 surface was prepared by using a solution of $20 \mathrm{mg} / \mathrm{l}$ instead of $500 \mathrm{mg} / \mathrm{l} \mathrm{Hp}$ in $0.01 \mathrm{M}$

136 acetate buffer, and the activation of the surface during immobilisation was reduced

137 from 7 minutes to 3 minutes. For regeneration of the sensor surface the concentration

138 of sodium dodecyl sulphate (SDS) was increased from $2 \mathrm{mM}$ to $3 \mathrm{mM}$. An extra

139 reconditioning step was added, in which $50 \mathrm{mM}$ glycine $\mathrm{pH} 9.5$ was injected over the

140 sensor surface for 30 seconds, after the ordinary regeneration step. Bovine Hp (Life

141 diagnostics, Clarkston, GA, USA) was used for immobilization and standards, and the

142 limit of detection (LOD) of the modified assay was $0.3 \mathrm{mg} / \mathrm{l}$.

144 SAA was determined using a commercial ELISA with a LOD of $0.3 \mathrm{mg} / \mathrm{l}\left(\right.$ Phase $^{\mathrm{TM}}$

145 Serum Amyloid A Assay, Tridelta Development Ltd, Wicklow, Ireland).

147 Measurement of the somatic cell count, total protein, whey protein and casein content,

148 casein number, fat and lactose content 
149 SCC in the bulk tank milk samples was measured by an electronic fluorescence based

150 cell counting technique (Fossomatic 5000, Foss, Hillerød, Denmark). Total protein,

151 fat and lactose contents were measured on fresh milk using mid infrared spectroscopy

152 (Fourier Transform Instrument, FT 120, Foss). The casein content was determined by

153 an indirect method which was described earlier (Åkerstedt et al. 2008).

154

155

Measurement of proteolysis

156 The extent of proteolysis in the milk sample was measured according to a

157 fluorescamine method as previously described (Wiking et al. 2002).

158

159

Measurement of coagulating properties

160 The coagulating properties of the milk was measured with a Bohlin VOR Rheometer

161 (Malvern Instruments Nordic AB, Uppsala, Sweden) according to Hallén et al. (2007)

162 with one minor modification, i.e. Chymax Plus, strength 200 IMCU per gram

163 (Christian Hansen A/S, DK-2970, Hørsholm, Denmark), was used instead of pure

164 chymosin. The coagulation time was measured, i.e. the time (s) elapsed from

165 chymosin addition until a weak coagulum corresponding to 5 Pa was formed. In

166 addition, curd firmness (Pa) was measured 25 min after chymosin addition.

168 Statistical analyses

169 Parametric t-test using SAS (Version 9.1, SAS Institute Inc., Cary, NC, USA) was

170 used to evaluate the relationships between APP and the different raw milk quality

171 parameters analysed. The bulk tank milk samples were categorised into two groups;

172 detectable or non-detectable levels of Hp or SAA, based on the detection limits of the

173 assays used to determine the proteins in milk. SCC and curd firmness were 
logarithmically transformed before statistical analyses to obtain normally distributed data. Differences between groups were considered significant if $\mathrm{p} \leq 0.05$.

\section{Results}

Descriptive statistics for the milk quality parameters analysed in the study are presented in Table 1. Detectable levels of Hp were found in 19 (21\%) of the 91 bulk tank milk samples. The average Hp concentration in these 19 samples was $1.02 \pm 0.99$ $\mathrm{mg} / \mathrm{l}$ and the average SCC in these samples was 387,000 $\pm 266,000$ cells/ml. Detectable levels of SAA were found in 68 (75\%) of the 91 bulk tank milk samples. The average SAA concentration in these 68 samples was $1.12 \pm 1.16 \mathrm{mg} / \mathrm{l}$ and the average SCC in these samples was $218,000 \pm 179,000$ cells/ml. Samples not containing detectable levels of Hp had the average SCC of 144,000 $\pm 78,000$ cells/ml while samples not containing detectable levels of SAA had the average SCC of $127,000 \pm 116,000$ cells/ml.

Table 1 near here.

Table 2 and 3 present differences in milk composition between samples with and without detectable levels of Hp and SAA, respectively. Bulk tank milk samples in which Hp could be detected had a lower casein number, contained less casein, had increased proteolysis, a lower lactose content and higher SCC compared to samples without detectable levels of Hp. Bulk tank milk samples in which SAA could be detected had a lower casein number, increased whey protein, lower lactose content and higher SCC compared to samples not containing detectable levels of SAA. 
199

200

201

202

203

204

205

206

207

208

209

210

211

212

213

Table 2, 3 and 4 near here.

In Table 4, results obtained for differences in milk composition between samples containing high BTMSCC ( $>195,000$ cells/ml) and low BTMSCC $(<195,000$ cells/ml) are presented. Samples with higher BTMSCC had lower casein number than samples with lower BTMSCC. In the high BTMSCC group, 16 of the 29 samples (55\%) contained Hp, while 26 of the 29 (90\%) samples contained SAA. In the low BTMSCC group, 3 of the 62 samples (5\%) contained Hp, while 42 of the 62 (68\%) contained SAA.

\section{Discussion}

The present study is, to our knowledge, the first investigating relationships between the quality of raw bulk tank milk and the presence of APP as indicator of mastitis. When studying markers for udder health disturbances and effects on milk composition it is important to have in mind that the type of milk sample, i.e. quarter, cow composite or bulk tank milk, may affect the results. Due to the dilution effect from quarter milk to composite and bulk tank milk, significant relationships found at quarter level may not be present at cow or bulk tank level and vice versa. However, the main findings of the present study, i.e. unfavourable changes in protein composition in bulk tank milk samples with detectable levels of APP, are largely in agreement with the results of our earlier study in cow composite milk (Åkerstedt et al. 2008).

In this study, bulk tank milk samples with detectable levels of Hp had lower casein content as well as lower casein number. This was most likely due to increased 
224 proteolytic activity, since these samples also had significantly higher proteolysis than samples without detectable levels of Hp. Bulk tank milk samples containing detectable levels of SAA also had a lower casein number compared to samples without detectable levels of SAA. In this case, however, the effect was likely due to the observed increased whey protein content in the samples. It is thus likely that 229 decreased synthesis, proteolysis and influx of components from the blood will occur 230 simultaneously but to evaluate to what extent was outside the scope of this paper.

231 In this study, detectable levels of Hp in bulk tank milk was related to increased 232 proteolytic activity, which is in contrast to the results in our previous study on cow 233 composite milk samples (Åkerstedt et al. 2008). One possible explanation for not 234 observing proteolysis in cow composite milk but in bulk tank milk may be related to 235 the fact that bulk tank milk consists of commingled milk from different milkings, as 236 well as milk from non-infected and sub-clinically infected glands (Leitner et al. 237 2008). Moreover, the storage time before collection and freezing was longer for bulk 238 tank, than for cow composite milk samples, allowing proteolysis to proceed for a 239 longer time. The bulk tank milk samples were collected at the dairy plant and were 240 kept at $+4^{\circ} \mathrm{C}$ during the entire chain from farm to laboratory. Since the milk is 241 collected every second day, the oldest batch of milk in the tank was stored for 242 approximately 2.5 days before it was frozen. Refrigerated storage of raw milk is 243 known to favor the growth of psychrotropic bacteria, which may produce heat244 resistant extra-cellular proteases and lipases. Proteases are mainly secreted at the end 245 of the log phase of the bacterial growth, at numbers in the order of $10^{7} \mathrm{cfu} / \mathrm{ml}$, 246 indicating that very high numbers of bacteria are required to result in proteolysis 247 (Sørhaug \& Stepaniak, 1997). In a study by Haryani et al. (2003), such high numbers 248 were reached first after 7 days at $4^{\circ} \mathrm{C}$, and proteolysis, as measured by the 
249 fluorescamine method, was observed on day 6. Considering the very high numbers of

250 bacteria needed for proteolysis to become a problem, it is unlikely that microbial

251 contamination of milk samples would explain the observed relationships between the

252 presence of $\mathrm{Hp}$ and increased proteolysis. An influence of microbial proteases cannot,

253 however, be excluded at this stage.

256 Bulk tank milk samples with detectable levels of SAA contained less lactose in 257 agreement with earlier studies on udder quarter and cow composite milk samples

258 (Lindmark-Månsson et al. 2006; Åkerstedt et al. 2008). In the present study, bulk tank 259 milk samples with detectable levels of Hp also contained reduced levels of lactose.

260 The most common explanation to decreased lactose content is reduced synthesis due

261 to damaged epithelial cells. Another explanation, suggested by Silanikove et al.

262 (2000), might be that proteolysis of $\beta$-casein will result in release of peptides with a

263 regulatory effect on lactose secretion.

265 Bulk tank milk samples with detectable levels of Hp and SAA had significantly higher

266 SCC compared to samples without Hp and SAA, respectively. In our previous study,

267 bulk tank milk samples with detectable levels of SAA, but not samples with

268 detectable levels of Hp, had higher SCC (Åkerstedt et al. 2007). The discrepancy

269 between the studies might be explained by the use of different statistical methods,

270 differences in the categorisation of the samples and the selection of milk samples. To

271 assess the potential of APP as markers for milk quality in comparison with the

272 commonly applied SCC, we also investigated relationships between SCC and the

273 different quality traits in the same samples. In this study, bulk tank milk samples with 
274 elevated SCC (>195,000 cells/ml), had a lower casein number than samples with a 275 lower SCC $(<195,000$ cells/ml). In our previous study (Åkerstedt et al. 2008) with 276 cow composite milk, samples with elevated SCC (>83,000 cells/ml) had reduced 277 lactose and increased whey protein content compared to samples with a lower SCC $278(<83,000$ cells $/ \mathrm{ml})$. The threshold values used in those studies (195 000 cells $/ \mathrm{ml}$ and 83,000 cells/ml) are median and mean values, respectively. These threshold values are relevant since several studies demonstrate that the composition is deteriorated on quarter and cow level between 50,000-100,000 cells/ml, while the Swedish milk payment system give additional bonus payment when the bulk tank contains less than $175,000-200,000$ cells/ml. Our studies suggest that the presence of APP in milk is 284 related to disadvantageous changes in several milk quality parameters and that these relationships are valid in both cow composite and bulk tank milk. SCC, on the other hand, is not related to milk quality traits to the same extent as APP and the type of relationships observed differs between cow composite and bulk tank milk.

No significant relationships between APPs and coagulation properties, i.e. coagulation time and curd firmness, were found in this study. Since there are no other studies 291 published investigating APP in relation to the coagulating properties of milk, it is 292 difficult to evaluate the results obtained. In earlier studies, significant correlations 293 between mastitis and impaired coagulating properties were observed (for review see 294 Munro et al. 1984). In contrast, Leitner et al. (2008) found no correlation between 295 coagulation time and SCC at bulk tank or silo level. In general, most published research on coagulating properties is based on studies with milk from a small number 297 of animals (Barbano et al. 1991; Mazal et al. 2007). It is also common that batches of 298 milk with a specific SCC are constructed by pooling milk with very high SCC, often 
originating from cows with clinical mastitis, and milk with a low SCC. Such a procedure is not ideal, as the composition of milk from cases of clinical mastitis is very deviant from milk originating from cows without clinical signs. Consequently, this type of constructed milk samples are not representative for real bulk tank milk samples, representing commingled milk from a large number of clinically healthy cows.

The casein content is an important quality parameter in cheese production and decreased casein content implies large losses for the dairy industry. At present, the total protein content is used as a major quality parameter, largely affecting the milk price to the producer. The total protein content, however, also includes the whey proteins, of which those originating from blood, with no interest for the dairies, will

311 increase during mastitis. The extent of proteolysis is another important factor

312 influencing milk quality, although not presently assessed. There are thus no

313 techniques in place allowing reliable, large-scale analyses of the protein quality of the

314 milk, although research and development in this field is ongoing. In a future 315 perspective, the dairies might have the possibility to differentiate raw milk based on quality to be used for different purposes. SCC is a good marker for udder health

317 disturbances at udder quarter level but several studies have demonstrated that SCC is 318 not a strong candidate for predicting the processing quality of the bulk tank milk (Le 319 Roux et al. 1995; Urech et al. 1999; Leitner et al. 2006; Leitner et al. 2008). Since many dairy products like cheese and fermented products require high protein quality it

321 should be of great importance to have a sensitive and specific marker for 322 disadvantageous changes in milk composition, e.g. those associated to poor udder 323 health. Changes in levels of such a marker should preferably be associated to the 
protein composition of the raw milk. In this study, Hp and SAA have shown to be potential candidates for predicting the raw bulk tank milk quality, specifically in relation to protein quality. This study and our previous studies therefore suggest that APP may be used as indicators for changes in milk composition as consequence of udder health disturbances, in quarter or cow composite milk samples at the farm, as well as in bulk tank milk at the dairy plant or milk grading laboratory. for financial support. We are also grateful to Malin Thors and Lotta Wall at the Department of Food Science for their technical assistance, the dairy cooperative MILKO for collaboration, and their helpful tanker drivers for assistance during milk sampling.

\section{References}

Åkerstedt M, Björck L, Persson Waller K \& Sternesjö Å 2006 Biosensor assay for determination of haptoglobin in bovine milk. Journal of Dairy Research 73 299-305

Åkerstedt M, Persson Waller K \& Sternesjö Å 2007 Haptoglobin and serum

344 amyloid A in relation to the somatic cell count at quarter, cow composite and bulk 345 tank milk samples. Journal of Dairy Research 74 198-203 
Åkerstedt M, Persson Waller K, Bach Larsen L, Forsbäck L \& Sternesjö Å 2008

Relationship between haptoglobin and serum amyloid A in relation to milk quality.

International Dairy Journal 18 669-674

Auldist MJ, Coats S, Sutherland BJ, Mayes JJ, McDowell GH \& Rogers GL

1996 Effects of somatic cell count and stage of lactation on raw milk composition and the yield and quality of cheddar cheese. Journal of Dairy Research 63 269-280

Barbano DM, Rasmussen RR \& Lynch JM 1991 Influence of milk somatic cell

count and milk age on cheese yield. Journal of Dairy Science 74 369-388

Barbano DM, Ma Y \& Santos MV 2006 Influence of raw milk quality on fluid milk shelf life. Journal of Dairy Science 89 (E.Suppl.):E15-E19

De Noni I, Pellegrino L, Cattaneo S \& Resmini P 2007 HPLC of proteose peptones for evaluating ageing of packaged pasteurized milk. International Dairy Journal 17 12-19

Eaton JW, Brandt P, Mahoney JR \& Lee JT 1982 Haptoglobin: A natural 
372 Eckersall PD 2004 The time is right for acute phase proteins assay. The Veterinary Journal 168 3-5

\section{Eckersall PD, Young FJ, Nolan AM, Knight CH, McComb C, Waterston MM,} Hogarth CJ, Scott EM \& Fitzpatrick JL 2006 Acute phase proteins in bovine milk in an experimental model of Staphylococcus aureus subclinical mastitis. Journal of Dairy Science 89 1488-1501

\section{Grönlund U, Hulten C, Eckersall PD, Hogarth C \& Persson Waller K 2003}

Haptoglobin and serum amyloid A in milk and serum during acute and chronic experimentally induced Staphylococcus aureus mastitis. Journal of Dairy Research $\mathbf{7 0}$ 379-386

\section{Grönlund U, Hallén Sandgren C \& Persson Waller K 2005 Haptoglobin and} serum amyloid A in milk from dairy cows with chronic sub-clinical mastitis.

Veterinary Research 36 191-198

\section{Hallén E, Allmere T, Näslund J, Andrén A \& Lundén A 2007 Effect of genetic} polymorphism of milk proteins on rheology of chymosin-induced milk gels.

\section{International Dairy Journal 17 791-799}

\section{Haryani S, Datta N, Elliott AJ \& Deeth HC 2003 Production of proteinases by} psychrotropic bacteria in raw milk stored at low temperature. Australian Journal of Dairy Technology 58 15-20 
Hari-Dass R, Shah C, Meyer DJ \& Raynes JG 2005 Serum amyloid A protein binds to outer membrane protein A of gram-negative bacteria. Journal of Biological Chemistry 280 18562-18567

400

Hiss S, Mielenz M, Bruckmaier R M \& Sauerwein H 2004 Haptoglobin concentrations in blood and milk after endotoxin challenge and quantification of mammary Hp mRNA expression. Journal of Dairy Science 87 3778-3784

404 quarters. Veterinarni Medicina 52 245-252

408

Horadagoda NU, Knox KMG, Gibbs HA, Reid SWJ, Horadagoda A, Edwards SER \& Eckersall PD 1999 Acute phase proteins in cattle: discrimination between

411 acute and chronic inflammation. Veterinary Record 144 437-441

413 Kelly AL, O’Flaherty FO \& Fox PF 2006 Indigenous proteolytic enzymes in milk:

414 A brief overview of the present state of knowledge. International Dairy Journal 16

$415 \quad 563-572$

417 Kitchen BJ 1981 Review of the progress of dairy science: Bovine mastitis: milk

418 compositional changes and related diagnostic tests. Journal of Dairy Research 48 $419 \quad 167-188$ 
421 Larsen LB, Rasmussen MD, Bjerring M \& Nielsen JH 2004 Proteases and protein 422 degradation in milk from cows infected with Streptococcus uberis. International Dairy Journal 14 899-907

Larson MA, Weber A, Weber AT \& McDonald TL 2005 Differential expression and secretion of bovine serum amyloid A (SAA3) by mammary epithelial cells stimulated with prolactin or lipopolysaccahride. Veterinary Immunology and Immunopathology 107 255-264

Leitner G, Krifucks O, Merin U, Lavi Y \& Silanikove N 2006 Interactions between bacteria type, proteolysis of casein and physico-chemical properties of bovine milk. International Dairy Journal 16 648-654 influence of storage on the farm and in dairy silos on milk quality for cheese production. International Dairy Journal 18 109-113

Le Roux Y, Colin O \& Laurent F 1995 Proteolysis in samples of quarter milk with varying somatic cell counts: 1 . Comparison of some indicators of endogenous

440 proteolysis in milk. Journal of Dairy Science 78 1289-1297 between somatic cell count, individual leukocyte populations and milk components in 
Ma Y, Ryan C, Barbano DM, Galton DM, Rudan MA \& Boor KJ 2000 Effects of somatic cell count on quality and shelf-life of pasteurized fluid milk. Journal of Dairy Science 83 264-274

449

Mara O, Roupie C, Duffy A \& Kelly AL 1998 The curd-forming properties of milk as affected by the action of plasmin. International Dairy Journal 8 807-812

452

Mazal G, Vianna PCB, Santos MV \& Gigante ML 2007 Effect of somatic cell count on prato cheese composition. Journal of Dairy Science 90 630-636

455

456

McDonald TL, Larson MA, Mack DR \& Weber A 2001 Elevated extrahepatic expression and secretion of mammary-associated serum amyloid A 3 (M-SAA3) into colostrum. Veterinary Immunology and Immunopathology 83 203-211

Munro GL, Grieve PA \& Kitchen BJ 1984 Effects of mastitis on milk yield, milk composition, processing properties and yield and quality of milk products. Australian Journal of Dairy Technology 39 7-16

463

Nielsen BH, Jacobsen S, Andersen PH, Niewold TA \& Heegaard PMH 2004

Acute phase protein concentrations in serum and milk from healthy cows, cows with clinical mastitis and cows with extramammary inflammatory conditions. Veterinary Record 154 361-365

468 
472 Santos MV, Ma Y \& Barbano DM 2003 Effect of somatic cell count on proteolysis 473 and lipolysis in pasteurized fluid milk during shelf-life storage. Journal of Dairy

474 Science 86 2491-2503

475

476 Schaar J 1985 Plasmin activity and proteose-peptone content of individual milks.

477 Journal of Dairy Research 52 369-378

478

479 Silanikove N, Shamay A, Shinder D \& Moran A 2000 Stress down regulates milk

480 yield in cows by plasmin induced $\beta$-casein product that blocks $\mathrm{K}+$ channels on the

481 apical membranes. Life Sciences 67 2201-2212

482

483 Sørhaug T \& Stepaniak L 1997 Psychrotrophs and their enzymes in milk and dairy

484 products: Quality aspects. Trends in Food Science \& Technology 18 35-41

485

486

Urech E, Puhan Z \& Schallibaum M 1999 Changes in milk fraction as affected by

487

subclinical mastitis. Journal of Dairy Science 82 2402-2411

488

489

Wiking L, Frost MB, Larsen LB \& Qvist KB 2002 Effects of storage conditions on

490 lipolysis, proteolysis and sensory attributes in high quality raw milk.

$491 \quad$ Milchwissenschaft 57 190-194

492

493

494

495

496

497

498

499 
Table 1. Milk composition, including contents of haptoglobin (Hp) and serum

509 amyloid A (SAA), and coagulating properties of 91 bulk tank milk samples.

510

511

\begin{tabular}{lllll}
\hline Parameter & Unit & Mean (SD) & Minimum & Maximum \\
\hline Hp & $\mathrm{mg} / \mathrm{l}$ & $\mathrm{ND}^{\dagger}$ & $<0.3$ & 4.70 \\
SAA & $\mathrm{mg} / \mathrm{ND}$ & $<.54(0.18)$ & 3.12 & 4.21 \\
Total protein & $\%$ & $2.58(0.14)$ & 2.20 & 3.07 \\
Casein & $\%$ & $0.73(0.01)$ & 0.71 & 0.75 \\
Casein number & & $0.91(0.05)$ & 0.82 & 1.09 \\
Whey protein & $\%$ & $1.11(0.11)$ & 0.89 & 1.71 \\
Proteolysis & eq leu & & & \\
Fat & $\%$ & $4.48(0.43)$ & 3.54 & 6.25 \\
Lactose & $\%$ & $4.61(0.11)$ & 4.30 & 4.91 \\
Somatic cell count & cells/ml & $195,000(169,600)$ & 33,000 & $1,365,000$ \\
Coagulation time & $\mathrm{s}$ & $120(42)$ & 32 & 278 \\
Curd firmness & Pa & $350(118)$ & 162 & 798 \\
\hline
\end{tabular}

${ }^{\dagger} \mathrm{ND}=$ not determined. Since many of the samples did not contain detectable levels of

514 Hp or SAA, i.e levels were below $0.3 \mathrm{mg} / \mathrm{l}$, it was not considered relevant to calculate 515 a mean value.

$516{ }^{\ddagger}$ eq leu = equivalent mM leucine. 
521 Table 2. Differences in milk composition between bulk tank milk samples with $\left(\mathrm{Hp}^{+}\right)$

522 and without (Hp-) detectable levels of Hp. Differences between $\mathrm{Hp}+$ and Hp- samples

523 were evaluated by parametric t-test and were considered significant if $\mathrm{p} \leq 0.05$.

524

\begin{tabular}{lccccc}
\hline & $\mathrm{Hp}+(\mathrm{n}=19)$ & $\mathrm{SE}^{\dagger}$ & $\mathrm{Hp}-(\mathrm{n}=72)$ & $\mathrm{SE}$ & $\mathrm{p}$-value \\
\hline Total protein (\%) & 3.493 & 0.025 & 3.549 & 0.023 & $\mathrm{NS}^{\ddagger}$ \\
Casein (\%) & 2.532 & 0.018 & 2.593 & 0.017 & 0.016 \\
Casein number & 0.725 & 0.001 & 0.731 & 0.001 & $<0.001$ \\
Whey protein (\%) & 0.913 & 0.008 & 0.908 & 0.006 & $\mathrm{NS}$ \\
Proteolysis (eq leu) & 1.159 & 0.019 & 1.100 & 0.014 & 0.038 \\
Fat (\%) & 4.455 & 0.049 & 4.491 & 0.055 & $\mathrm{NS}$ \\
Lactose (\%) & 4.579 & 0.014 & 4.618 & 0.014 & 0.05 \\
Log SCC (cells/ml) & 5.528 & 0.049 & 5.104 & 0.027 & $<0.001$ \\
Coagulation time (s) & 110 & 9.862 & 123 & 4.963 & $\mathrm{NS}$ \\
Log curd firmness (Pa) & 2.547 & 0.039 & 2.517 & 0.015 & $\mathrm{NS}$ \\
\hline
\end{tabular}

${ }^{\dagger} \mathrm{SE}=$ Standard Error

${ }^{\ddagger} \mathrm{NS}=$ not significant

$\S$ eq leu = equivalent mM leucine. 
Table 3. Differences in milk composition between bulk tank milk samples with

545 (SAA+) and without (SAA-) detectable levels of SAA. Differences between SAA+

546 and SAA- samples were evaluated by parametric t-test and were considered

547 significant if $\mathrm{p} \leq 0.05$.

548

\begin{tabular}{lccccc}
\hline & SAA+ $(\mathrm{n}=68)$ & $\mathrm{SE}^{\dagger}$ & SAA- $(\mathrm{n}=23)$ & $\mathrm{SE}$ & $\mathrm{p}$-value \\
\hline Total protein (\%) & 3.553 & 0.021 & 3.488 & 0.042 & $\mathrm{NS}^{\ddagger}$ \\
Casein (\%) & 2.588 & 0.016 & 2.559 & 0.032 & $\mathrm{NS}$ \\
Casein number & 0.728 & 0.001 & 0.734 & 0.001 & $<0.001$ \\
Whey protein (\%) & 0.918 & 0.006 & 0.883 & 0.011 & 0.004 \\
Proteolysis (eq leu) & 1.122 & 0.014 & 1.082 & 0.023 & $\mathrm{NS}$ \\
Fat (\%) & 4.477 & 0.049 & 4.504 & 0.102 & $\mathrm{NS}$ \\
Lactose (\%) & 4.583 & 0.012 & 4.692 & 0.018 & $<0.001$ \\
Log SCC (cells/ml) & 5.261 & 0.029 & 4.989 & 0.063 & $<0.001$ \\
Coagulation time (s) & 122 & 5.055 & 113 & 9.276 & $\mathrm{NS}$ \\
Log curd firmness (Pa) & 2.521 & 0.016 & 2.533 & 0.030 & $\mathrm{NS}$ \\
\hline
\end{tabular}

${ }^{\dagger} \mathrm{SE}=$ Standard Error

${ }^{\ddagger} \mathrm{NS}=$ not significant

$\S$ eq leu = equivalent mM leucine.

553

554

555

556

557

558

559 
563

564

565

566

567

568

569

570

571

\begin{tabular}{lccccc}
\hline & $\begin{array}{c}\text { high SCC } \\
(\mathrm{n}=29)\end{array}$ & $\mathrm{SE}^{\dagger}$ & $\begin{array}{c}\text { low SCC } \\
(\mathrm{n}=62)\end{array}$ & SE & p-value \\
\hline Total protein (\%) & 3.498 & 0.027 & 3.555 & 0.025 & NS \\
Casein (\%) & 2.541 & 0.021 & 2.599 & 0.018 & NS \\
Casein number & 0.726 & 0.001 & 0.731 & 0.001 & 0.002 \\
Whey protein (\%) & 0.909 & 0.008 & 0.909 & 0.007 & NS \\
Proteolysis (eq leu) & 1.126 & 0.020 & 1.105 & 0.014 & NS \\
Fat (\%) & 4.453 & 0.059 & 4.498 & 0.060 & NS \\
Lactose (\%) & 4.585 & 0.014 & 4.622 & 0.015 & NS \\
Coagulation time (s) & 118 & 8.053 & 121 & 5.359 & NS \\
Log curd firmness (Pa) & 2.507 & 0.030 & 2.531 & 0.015 & NS \\
\hline
\end{tabular}

Table 4. Differences in milk composition between bulk tank milk samples with high SCC (>195,000 cells/ml) and low SCC (<195,000 cells/ml). Differences between high SCC and low SCC samples were evaluated by parametric t-test and were considered significant if $\mathrm{p} \leq 0.05$.

572

$573+$ SE $=$ Standard Error

$574{ }^{\ddagger} \mathrm{NS}=$ not significant

$575 \S$ eq leu = equivalent $\mathrm{mM}$ leucine.

576

577 